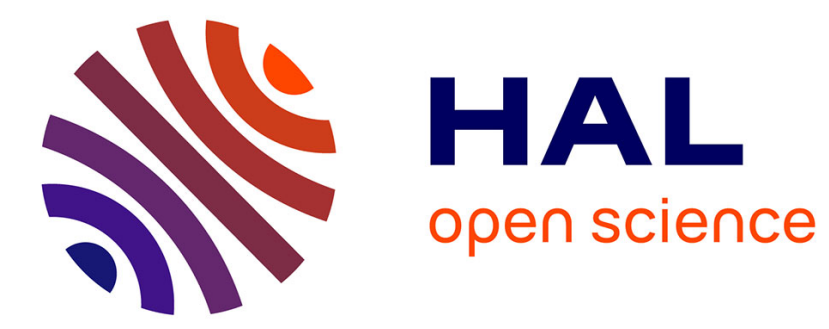

\title{
Internal Friction in L.A.S. Type Glass and Glass-Ceramics
}

L. Arnault, A. Rivière

\section{To cite this version:}

L. Arnault, A. Rivière. Internal Friction in L.A.S. Type Glass and Glass-Ceramics. Journal de Physique IV Proceedings, 1996, 06 (C8), pp.C8-683-C8-686. 10.1051/jp4:19968148 . jpa-00254581

\section{HAL Id: jpa-00254581 https://hal.science/jpa-00254581}

Submitted on 1 Jan 1996

HAL is a multi-disciplinary open access archive for the deposit and dissemination of scientific research documents, whether they are published or not. The documents may come from teaching and research institutions in France or abroad, or from public or private research centers.
L'archive ouverte pluridisciplinaire HAL, est destinée au dépôt et à la diffusion de documents scientifiques de niveau recherche, publiés ou non, émanant des établissements d'enseignement et de recherche français ou étrangers, des laboratoires publics ou privés. 


\title{
Internal Friction in L.A.S. Type Glass and Glass-Ceramics
}

\author{
L. Arnault and A. Rivière \\ LMPM, ENSMA, BP. 109, 86960 Futuroscope cedex, France
}

\begin{abstract}
Internal friction measurements have been performed on glass and glass-ceramics of the $\mathrm{Li}_{2} \mathrm{O}-\mathrm{Al}_{2} \mathrm{O}_{3}-\mathrm{SiO}_{2}$ type by isothermal mechanical spectroscopy. Experiments were carried out over a large frequency range $\left(10^{-4} \mathrm{~Hz}-31.6 \mathrm{~Hz}\right)$ for various temperatures between $260 \mathrm{~K}$ and $850 \mathrm{~K}$. For the glass, a relaxation peak is observed at low temperature $(276 \mathrm{~K}$ for $1 \mathrm{~Hz})$. This peak does not appear in the glass-ceramics; however, for each of them, two other peaks were observed: the first one at about $343 \mathrm{~K}(1 \mathrm{~Hz})$ and the second one at higher temperature, between $600 \mathrm{~K}$ et $700 \mathrm{~K}(1 \mathrm{~Hz})$. Our dielectric loss investigation data obtained on the same materials have allowed to assume that the low-temperature peaks are due to the stress-induced diffusion of $\mathrm{Li}^{+}$ions, in the vitreous phase for the glass and in the crystal phase for the glass-ceramics respectively. The peaks observed at higher temperature in glass-ceramics depend on the crystal phase but the relaxation mechanisms responsible of them are not well defined.
\end{abstract}

\section{INTRODUCTION}

Contrary to binary silicate glasses which have been largely studied [1-3], only few internal friction investigations have been performed on more complex glasses which can be converted into glass-ceramics and on the glass-ceramics themselve [4-6]. This work is about the investigation, by isothermal mechanical spectrometry, of L. A. S. type glass and glass-ceramics, with identical chemical composition, between $77 \mathrm{~K}$ and $800 \mathrm{~K}$. It seems interesting to study and compare the internal friction of these materials in order to observe changes in microstructure due to crystallization and to estimate the contribution of the glassy and crystalline phases. In order to obtain further information on the relaxation phenomena, dielectric measurements have been performed on these materials.

\section{EXPERIMENTAL PROCEDURE}

\subsection{Materials}

The materials investigated are a glass (A) and two glass-ceramics ( $\mathrm{B}$ and $\mathrm{C}$ ) of the $\mathrm{Li}_{2} \mathrm{O}-\mathrm{Al}_{2} \mathrm{O}_{3}-\mathrm{SiO}_{2}$ system provided by Corning Europe Inc. The three materials have the same composition (\%wt): $70 \mathrm{SiO}_{2}$ $20 \mathrm{Al}_{2} \mathrm{O}_{3}-6\left(\mathrm{Li}_{2} \mathrm{O}+\mathrm{MgO}+\mathrm{ZnO}\right)-4\left(\mathrm{TiO}_{2}+\mathrm{ZrO}_{2}\right)$.

Glass $\mathrm{A}$, after submitting to two different controlled heat treatments, was converted in glass-ceramic $\mathrm{B}$ and $\mathrm{C}$ respectively. Glass-ceramic $\mathrm{B}$ is transparent and is primarily composed of $\beta$-quartz solid solution crystals $\left.\left(\mathrm{Li}_{2} \mathrm{O}-\mathrm{Al}_{2} \mathrm{O}_{3}-\mathrm{nSiO}\right)_{2}\right)$. Glass-ceramic $\mathrm{C}$ is opaque and its main crystalline phase is $\beta$-spodumene $\left(\mathrm{Li}_{2} \mathrm{O}-\mathrm{Al}_{2} \mathrm{O}_{3}-4 \mathrm{SiO}_{2}\right)$. The crystallinity rate of these glass-ceramics is about $90 \%$.

\subsection{Experimental techniques}

Internal friction measurements were performed with an inverted torsional pendulum with a high natural frequency subjected to subresonant forced oscillations. With this method the internal friction $Q^{-1}$ is equal to $\tan \phi$, where $\phi$ is the phase lag angle between applied stress and resulting strain.

The experimental system was described in details elsewhere [7]. Internal friction measurements were carried out in isothermal conditions as a function of frequency on a wide range $\left[10^{-4} \mathrm{~Hz}-30 \mathrm{~Hz}\right]$, between 
$77 \mathrm{~K}$ and $800 \mathrm{~K}$, with strain amplitude ranged between $5.10^{-6}$ and $20.10^{-6}$. The $\mathrm{Q}^{-1}$ accuracy is about $2.10^{-4}$ and the sample were cut in flat bars $\left(50 \times 5 \times 1.5 \mathrm{~mm}^{3}\right)$.

The dielectric loss measurements were carried out at various stabilized temperatures between room temperature and $500 \mathrm{~K}$ under partial pressure of $\mathrm{N}_{2}$ in the frequency range [20 Hz-10 $\left.0^{6} \mathrm{~Hz}\right]$ with a HP 4284 bridge which allows to measure the values of the equivalent capacitance $C_{p}$ and resistance $R_{p}$ of each sample. The specimens were flat parallelepipeds (thickness: $1 \mathrm{~mm}$ ) covered by a circular silver film (diameter: $10 \mathrm{~mm}$ ) in order to improve the electrical contact with the electrodes. The values of $\varepsilon^{\prime \prime}$ (imaginary part of the complex permittivity $\varepsilon^{*}$ ), is obtained from the values of $\mathrm{Rp}$ and $\mathrm{C}_{\mathrm{o}}$ (capacitance in vacuum).

\section{RESULTS}

For glass $\mathrm{A}$, the internal friction spectrum in the temperature range investigated [200 K-850 K] can be separated in the relaxation peak $\mathrm{P}_{1 \mathrm{~A}}$ below room temperature and a high temperature increasing background (Figure 1).The peak $P_{1 \mathrm{~A}}$ occurs at $276 \mathrm{~K}$ for $1 \mathrm{~Hz}$; it is asymmetrical and is too wide to be entirely described on a spectrum against frequency.

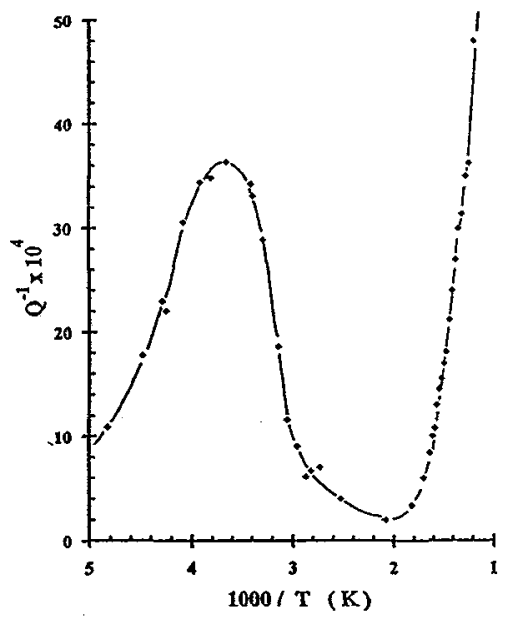

Figure 1

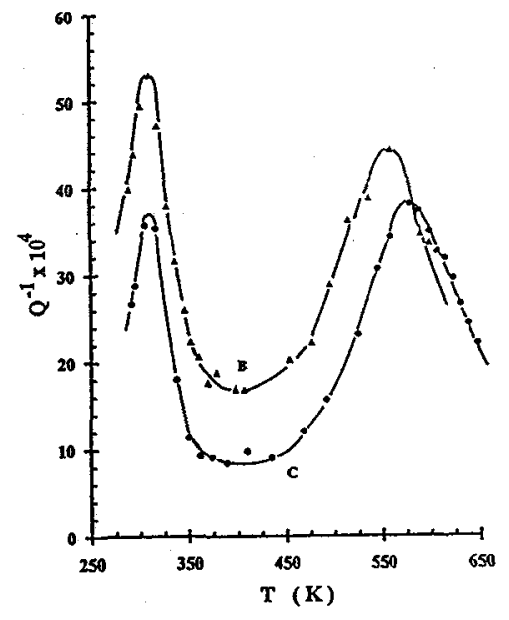

Figure 2

Figure 1: Glass A: internal friction versus 1000/T spectrum - measurement frequency: $1 \mathrm{~Hz}$ -

Figure 2: Glass-ceramics B and C: internal friction versus temperature spectrum - measurement frequency:3.16 $\times 10^{-2} \mathrm{~Hz}-$

For glass-ceramic $B$, two internal friction peaks $\left(P_{1 B}\right.$ and $\left.P_{2 B}\right)$ are observed from the isothermal $Q^{-1}$ measurements performed on a large temperature range (between room temperature and $700 \mathrm{~K}$ ). Like material $B$, two internal friction peaks $\left(P_{1 C}\right.$ and $\left.P_{2 C}\right)$ are observed for glass-ceramic $C$ for the same investigated temperature range. The $\mathrm{Q}^{-1}$ data are plotted against measurement temperature for a given frequency $\left(3.16 \times 10^{-2} \mathrm{~Hz}\right)$ in Figure 2 . For this frequency, $P_{1 B}$ and $P_{2 B}$ occur at $325 \mathrm{~K}$ and $556 \mathrm{~K}$ while $\mathrm{P}_{1 \mathrm{C}}$ and $\mathrm{P}_{2 \mathrm{C}}$ are located at $310 \mathrm{~K}$ and $579 \mathrm{~K}$ respectively.

The features of all these peaks (height: $h$, peak temperature at $1 \mathrm{~Hz}: T_{p}$ and the width at half maximum expressed in decade of frequency: $\delta$ ) are listed in Table 1.

For dielectric measurements carried out on each material A, B and C, between room temperature and $500 \mathrm{~K}$, the loss factor $\varepsilon$ " exhibits a high exponential low frequency background. After substraction of this background a dielectric relaxation peak is revealed. 


\section{DISCUSSION}

Arrhenius plots are drawn in Figure 3 for the low temperature internal friction and dielectric peaks of the three materials $A, B$ and $C$. There are three distinct straight lines, each of them corresponding to one of the three materials; for each material $(A, B$ or $C)$, the points arising from mechanical and dielectric relaxation peaks are on the same straight line. That means that for every particular material $(A, B, C)$ at stake, the relaxation mechanisms, responsible for the mechanical and dielectric peaks at relatively low temperature, are the same. Thus, the relaxation units responsible for the peaks $P_{1 A}, P_{1 B}$ and $P_{1 C}$ are electrically charged. It should be mentioned that the straight line concerning $P_{1 \mathrm{~A}}$ is well separated from the two others. The Arrhenius plots relative to the internal friction peaks $P_{2 B}$ and $P_{2 C}$ are shown in Figure 4. The apparent activation energy $\left(E_{a}\right)$ and the limit relaxation time $\left(\tau_{o}\right)$, deduced from the Arrhenius plots are summed up in Table 1 . The peaks $P_{1 B}$ and $P_{1 C}$ have close features but the relaxation parameters of $P_{1 A}$ are different from those of $P_{1 B}$ and $P_{1 C}$. The peaks $P_{2 B}$ and $P_{2 C}$ are different and it seems obvious that they are due to two distinct mechanisms.

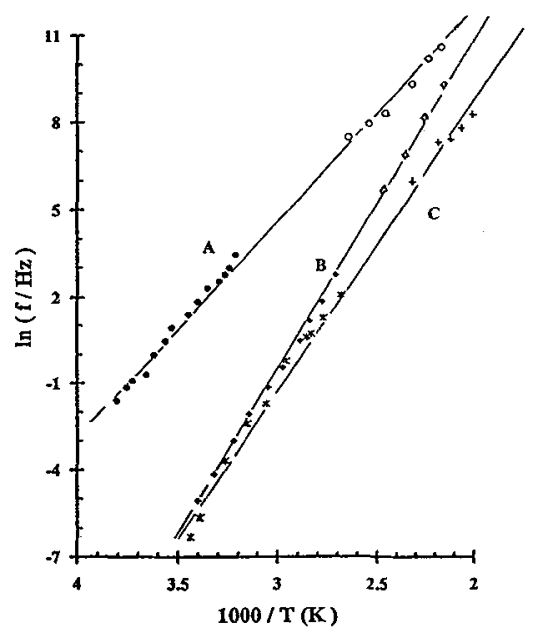

Figure 3

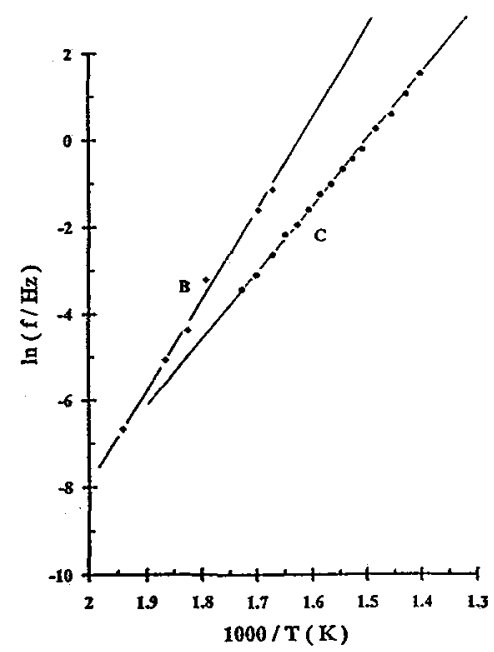

Figure 4

Figure 3: Arrhenius plots of mechanical $(\bullet,+, *)$ and dielectric $(0,0,+)$ relaxation phenomena observed at low temperature for sample A,B, C respectively.

Figure 4: Arrhenius plots of internal friction peaks $P_{2 B}$ and $P_{2 C}$.

Table 1:Relaxation parameters of peaks $P_{1 A}, P_{1 B}, P_{1 C}, P_{2 B}$ and $P_{2 B}$.

\begin{tabular}{|l|c|c|c|c|c|}
\cline { 2 - 6 } \multicolumn{1}{c|}{} & $\mathrm{P}_{1 \mathrm{~A}}$ & $\mathrm{P}_{1 \mathrm{~B}}$ & $\mathrm{P}_{1 \mathrm{C}}$ & $\mathrm{P}_{2 \mathrm{~B}}$ & $\mathrm{P}_{2 \mathrm{C}}$ \\
\hline $\mathrm{E}_{\mathrm{a}}(\mathrm{eV})$ & 0.63 & 1.0 & 0.88 & 1.8 & 1.3 \\
\hline$\tau_{\mathrm{o}}(\mathrm{s})$ & $4.5 \times 10^{-13}$ & $2.4 \times 10^{-16}$ & $2 \times 10^{-14}$ & $4 \times 10^{-16}$ & $2.6 \times 10^{-11}$ \\
\hline $\mathrm{T}_{\mathrm{p}}(\mathrm{K})$ & 276 & 340 & 345 & 615 & 665 \\
\hline$\delta$ & $>4.8$ & 2.8 & 2.8 & 2.2 & 2.6 \\
\hline $\mathrm{h} \times 10^{4}$ & 40 & 37 & 29 & 27 & 30 \\
\hline
\end{tabular}

Several facts suggest that the low-temperature internal friction peak $P_{1 A}$ observed in glass $A$ is due to the stress-induced diffusion of lithium ions. $P_{1 \mathrm{~A}}$ is characterized by an activation energy of $0.63 \mathrm{eV}$ close to those found by some authors for alkali ions relaxation. According to many studies, the low- temperature internal friction peak, ascribed to the stress controlled movement of alkali ions, appears below $273 \mathrm{~K}$ (about $238 \mathrm{~K}$ for $1 \mathrm{~Hz}$ ) [1], but the addition of $\mathrm{Al}_{2} \mathrm{O}_{3}$ [8] and alkali-earth oxides (such as $\mathrm{MgO}, \mathrm{CaO}$ ) [9] 
cause the shift of this peak to higher temperature (above $273 \mathrm{~K}$ ). As glass A belongs to a complex L.A.S system which contains, among other components, alkali earth oxide $(\mathrm{MgO})$, the position of $\mathrm{P}_{1 \mathrm{~A}}$ slightly above $273 \mathrm{~K}$ is in agreement with the previous observations. Furthermore, according to the studies of $\mathrm{Li}$ et al. on the influence of the crystallization process in some oxide glasses, such as $\mathrm{K}_{2} \mathrm{O}-\mathrm{Li}_{2} \mathrm{O}-\mathrm{Al}_{2} \mathrm{O}_{3}-\mathrm{SiO}_{2}$ $[5,6]$ and $\mathrm{MgO}-\mathrm{Al}_{2} \mathrm{O}_{3}-\mathrm{SiO}_{2}-\mathrm{TiO}_{2}$ [5], it seems obvious that the peak observed at low temperature in $\mathrm{K}_{2} \mathrm{O}-\mathrm{Li}_{2} \mathrm{O}-\mathrm{Al}_{2} \mathrm{O}_{3}-\mathrm{SiO}_{2}$ glass is linked with the presence of alkali ions. The peak $\mathrm{P}_{1 \mathrm{~A}}$ observed in glass does not appear in the two glass-ceramics B and C. Day and Rindone, in the study of the partly crystallized $\mathrm{Li}_{2} \mathrm{O}-2.75 \mathrm{SiO}_{2}(+0.0005 \% \mathrm{Pt})$ glass [4], noticed that the low-temperature peak linked with alkali ion diffusion markedly decreased with the increasing crystallinity and also disappeared when the amount in the crystal is very high $(\sim 78 \%)$ ). The fact that the peaks $\mathrm{P}_{1 \mathrm{~B}}, \mathrm{P}_{1 \mathrm{C}}, \mathrm{P}_{2 \mathrm{~B}}$ and $\mathrm{P}_{2 \mathrm{C}}$, which occur in the glassceramics are not observed in glass $\mathrm{A}$, is in agreement with the study of $\mathrm{Li}$ et al. They observed that for the $\mathrm{K}_{2} \mathrm{O}-\mathrm{Li}_{2} \mathrm{O}-\mathrm{Al}_{2} \mathrm{O}_{3}-\mathrm{SiO}_{2}$ system glass-ceramic after crystallization, the peak observed in the glass has disappeared, however, two other internal friction peaks are present at higher temperature. Thus the peaks $\mathrm{P}_{1 \mathrm{~B}}, \mathrm{P}_{1 \mathrm{C}}, \mathrm{P}_{2 \mathrm{~B}}$ and $\mathrm{P}_{2 \mathrm{C}}$ are certainly linked with relaxation mechanisms occuring in the crystalline phase.

There is a great similarity for the peak position and activation energy between the peaks $P_{1 B}, P_{1 C}$ and the first peak observed in the $\mathrm{K}_{2} \mathrm{O}-\mathrm{Li}_{2} \mathrm{O}-\mathrm{Al}_{2} \mathrm{O}_{3}-\mathrm{SiO}_{2}$ glass-ceramic, which appears at $343 \mathrm{~K}$ at $1 \mathrm{~Hz}$ and has an activation energy of $0.96 \mathrm{eV}$ [5]. Furthermore, as previously deduced, $P_{1 \mathrm{~B}}$ and $\mathrm{P}_{1 \mathrm{C}}$ are due to electrically charged entities. So, it is likely that the relaxation phenomena of $P_{1 B}$ and $P_{1 C}$ involve the lithium ions of the crystalline phase. However, as shown in Table $1, P_{1 B}$ has a higher magnitude than $P_{1 C}$ and the relaxation parameters $\left(E_{a}, \tau_{0}\right)$ of these peaks are slightly different. These divergences could be explained by a different environment for the $\mathrm{Li}^{+}$ions of the crystal phase because $\mathrm{B}$ and $\mathrm{C}$ have different crystalline structure (hexagonal system for $B$ and tetragonal for $C$ ).

As shown in Figures 2 and 4, it seems obvious that the relaxation phenomena responsible for $P_{2 B}$ and $P_{2 C}$ respectively are different. Furthermore, the disparity between the $E_{a}$ and $\tau_{o}$ values suggests that the relaxation units involved are not the same. As it was not possible to perform dielectric measurements in the appropriate temperature range, no information is available about the nature of the relaxation entities.

\section{CONCLUSION}

The investigated glass, which derived from the L.A.S. system, shows an internal friction peak close to $273 \mathrm{~K}$, attributed to the stress-induced diffusion of lithium ions. After crystallization heat treatement, this peak does not appear any more but for each glass-ceramic two other peaks are observed. The first one, at low temperature (about $343 \mathrm{~K}$ for $1 \mathrm{~Hz}$ ), is linked with $\mathrm{Li}^{+}$ions of the crystalline phase and its characteristics depend on the microstructural environment of lithium ions. The second one, which appears at higher temperature (between 600 and $700 \mathrm{~K}$ ) is largely different according to the considered glass-ceramic. This peak is due to entities which relax in the crystalline phase but the relaxation units and mechanisms implied are not identified.

\section{References}

[1] Zdaniewski W.A., Rindone G. E., Day D. E., J. Mater. Sci., 14 (1974) 763-775.

[2] Forry K.E., J. Am. Ceram. Soc., 45 (1957) 90-94.

[3] Taylor T. D., Rindone G. E., Relax. Proc. in Glasses, (Day D. E. Ed., North Hol. Pub. Co,1974) 157

[4] Day. D.E , Rindone G.E., J. Am. Ceram. Soc., 44 (1961) 161-167.

[5] Li J., J. Non-Cryst. Solids, 80 (1986) 1-10.

[6] Li J., Luo J., Chen H., Scienta Sinica, 13 (1964) 1888-1894.

[7] Woirgard J., Sarrazin Y., Chauvet H., Rev. Sci. Instrum., 48 (1977) 1322-1325.

[8] Day D.E, Rindone G.E., J. Am. Ceram. Soc., 45 (1962) 496-504.

[9] Ryder R.J., Rindone G.E., J. Am. Ceram. Soc., 43 (1960) 662-669. 